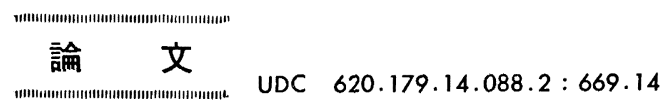

\title{
熱間渦流探傷における雑音の解析と㾟検出精度の向上*
}

\author{
渡辺一雄 ${ }^{* *}$. 武内晃 ${ }^{* *}$. 宇津野光朗**. 稲森 宏夫***
}

\section{Analysis of the Noise and Improvement of the Flaw Detecting Ability on the Eddy Current Flaw Detector for Hot Wire Rod}

Kazuo Watanabe, Akira Takenouchi, Mitsuo Utsuno, and Hiroo InAmori

\begin{abstract}
Synopsis:
Recently, various eddy current flaw detectors have been used in the wire rod mill for the quality control, but, in general, these flaw detectors have been unable to detect the flaw below $0.15 \mathrm{~mm}$ depth due to the various noises.

In this paper, the analysis of the noise and the improvement of $\mathrm{S} / \mathrm{N}$ by the phase discrimination are described.

From the result of the frequency analysis of the noise, it was confirmed that the nois was generated mainly due to the vibration of the wire rod in the search coils and such a noise could not be fully decreased by the frequency filter or by the phase discrimination in the case of $40 \mathrm{kHz}$ carrier frequency.

Accordingly, the new flaw detector with $160 \mathrm{kHz}$ carrier frequency which enables decrease the noise by the phase discriminator was developed and could detect the small flaw as $0.1 \mathrm{~mm}$ depth.

This flaw detector has been installed and in operation satisfactorily at the Hoshizaki Plant.
\end{abstract}

\section{1. 緒言}

最近，熱間圧延中の線材あるいは棒鋼の表面疵を検出 する熱間渦流探傷機が市肘され，品質管理用として，す でに各所において使用されている12)。従来から，線材 压延の品質管理には，圧延終了直後の線材コイルの端末 から採取した試料による抜き取り検査が行なわれている が，熱間渦流探傷機を邂用すれば，線材の全長検查がで き，かつ自動的に，迅速に情報を得ることができるので 有利である.

一般に鋼材は常温にて磁性を有するため，常温の鋼材 に渦流探傷を適用する場合は，鋼材の磁性の部分的な变 化が原因とみられる雑音が発生し， あまり高い検出精度 が得られない，一方，熱間渦流探傷では，磁性が消滅す るキューリ一点以上の高温の鋼材を探傷するため, 磁性 に起因する雑音は全く発生せず，検出精度は良好なはず である。しかし，熱間渦流探第機の使用洔には，雑音が かなり存在し，必ずしも予期されるような高㭘出精度が 得られないこの熱間における雑音の発生原因は鋼材の
肌荒れであるという考えもあるが，特に雑音の発生原因 についての詳細な研究はない。

筆者らは，市販単体計器と自社製作部分の組み合せに 上る, 搬送周波数 $40 \mathrm{kHz}$ の熱間渦流探傷機を製作し， 当社星崎工場線材圧延工場にて稼動させたが3) , 検出下 限の疵深さは $0.15 \mathrm{~mm}$ であつた. この探第機の適用過 程において, 特に雑音の発生原因について調查し, 雑音 の主原因が検出コイル中における線材の振動であること をつきとめ，雑音を減少するには位相弁別によらざるを えないとの結論を得た.

次に，最高搬送周波数 $160 \mathrm{kHz}$ の探傷機を製作し，同 線材工場に適用した結果, $5.5 \mathrm{~mm}$ 径の線材に対して $160 \mathrm{kHz}$ の搬送周波数を用いることにより, 疵信号と雑 音の位相差を大きくすることができ，位相弁別により雑 音を消去し， $0.1 \mathrm{~mm}$ 深さの疵まで梌出することができ た.

\section{2. 探傷機の構成}

搬送周波数 $160 \mathrm{kHz}$ の探傷機について構成を述べる.

* 昭和 49 年 12 月 5 日受付 (Received Dec. 5, 1974)

** 大同製鋼 (株) 研究開発本部 (Daido Steel Co., Ltd., 2-30 Daido-cho, Minami-ku, Nogoya 457)

****大同製銅 (株) 星崎工場 (Daido Steel Co., Ltd.) 


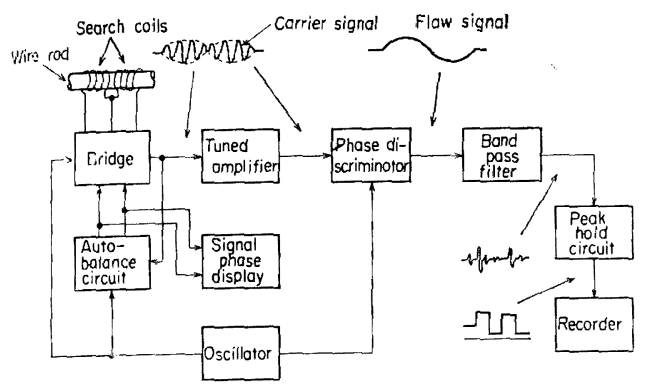

Fig. 1. Block diagram of eddy current flaw detector.

ブロックダイヤグラムを Fig. 1 亿示す.

検出コイルは2 個の同形のコイルを逆方向に接続した 自己比較型であり，Fig. 2 に示すごとく，固定抵抗とと もににマクスウェルブリッジを構成している．検出コイ ルの設計については，検出すべき最小長さの疵信号と線 材表面の肌荒れに起因する雑音との分離をよくするとい う観点からコイル長さを決定する方法が報告されてい る5)が，今回，この報告を参考にして，コイル長さは 13 $\mathrm{mm}$, コイル間隔は $5 \mathrm{~mm}$, コイル全長を $31 \mathrm{~mm}$ とし た. 検出感度を高くするため, コイルインピーダンスに 比べてリアクタンスを大きくとる必要があるが，今回用 いたコイルでは, $160 \mathrm{kHz}$ に対してインピーダンスは, $30 \Omega$ ，抵抗 $0.5 \Omega$ である. また $5.5 \mathrm{~mm}$ 径線材に対し 充填索は 0.18 である.

使用中におけるブリッジの不平衡を修正するオートバ ランス機構は, ブリッジ出力電生をブリッジ電源電瓜と 同相の成分と $90^{\circ}$ 位相の異なつた成分に分離し, これら の信号によりサーボモータを駆動し，Fig. 2 に示した抵 抗 $r_{1}, r_{2}$ を变化させる方法である. また，この同相成分 と $90^{\circ}$ 位相の異なつた信号は，それぞれブラウン管のX

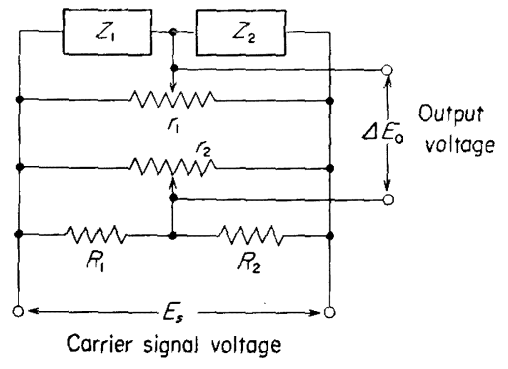

$Z_{1}, Z_{2}:$ Coil impedances

$R_{1}, R_{2}:$ Resistances

$r_{1}, r_{2}$ : Balancing resistances

Fig. 2. Bridge circuit.

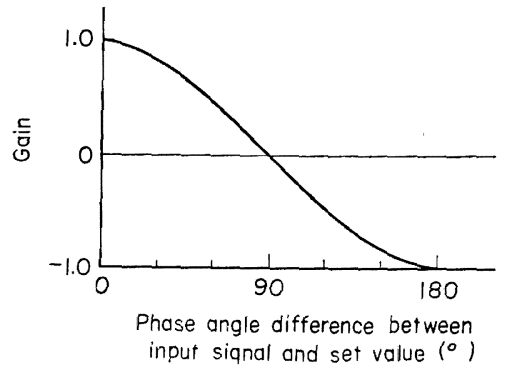

Fig. 3. Gain characteristics of phase discriminator.

棘とY軸に入力され，ブラウン管上の輝点の位置は， 4.2 にて述べるように，コイルインピーダンスをX軸と 一致させた場合のインピーダンス変化分のベクトルを表 わす. この表示器は位相角表示器として, 位相弁別器の 位相設定用モニタに使用される.

位相弁別は，発振器の信号からある位相角だけ移相さ れた矩形波によつて入力信号をゲートし，ゲートした部 分のみを平滑にする方法である. 特性は Fig. 3 に示す ごとく設定位相角と信号位相角の差に対して余弦関数で あり，設定位相角付近の位相角を持つた信号のみを通過 させるというような急峻な特性ではない。したがつて， 疵信号の通過率が 1 となるように設定した場合，たとえ ば，雑晋が疵信号位相角より $45^{\circ}$ 異なつた位相角である 場合, 雑音の通過率は 0.7 となる。しかし, 雑音の位相 角が通過率零の点に合值するよう設定位相角を設定すれ ば，雑音の通過率が零であるのに対し，疵信号の通過率 は 0.7 となり, 疵信号と雑音の通過率の比は大きくとれ る.实際の使用にあたつては，乙の方法によつた。

位相弁別器の出力は, さらにバンドパスフィルタによ り，周波数によつて疵信号が雑音より分蜼される.

㾟信号は数 $\mathrm{m} \mathrm{sec} の$ 信号であり，一般の記録計では 応答速度が不十分なので, 一定時間ごとのピーク值を保 持する回路を設けた. 後出の Fig. 11 などに示す探傷チ ヤートは, すべてピーク值保持回路後の信号の記録であ る. 保持洔間は $300 \mathrm{~m} \mathrm{sec}$ である。

検出コイルの外観を Photo. 1 に, 探伤機本体の外観 をPhoto. 2 に示す.

\section{3. 雑音の解析}

探伤機の证検出精度をあげるため，雑音の解析を行な い発生原因を追求した。

雑音の原因としては, 材料の電文伝導度や直径などの 部分的な変化，肌荒れ，材料の振動などが考えられる. まず，材料の振動の少ない条件における本探傷機の趾检 


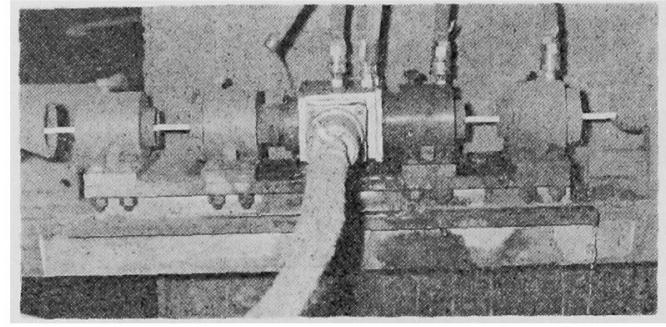

Photo. 1. Appearance of search coil.

出精度を知るために，常温にてオーステナイト采ステン レス鋼の压延線材を $1.5 \mathrm{~m} / \mathrm{sec}$ の低速度で走行させ探傷 を行なつた. その記録を Fig. 4 に示す. 酸洗後やすり がけによる肉眼検査と照合したところ，0.05 mm 深さ の疵まで検出していることがわかつた. $0.05 \mathrm{~mm}$ 深さ の疵信号より小さい信号も明確に再現性があるところか ら，乙れらの信号は電気伝導度や形状の部分的な变化， 肌荒れなど材料自体に起因するものであり，材料の振動 に起因するものではないと考えられる.

上述のことは, もし压延線材自体の部分的な変化や肌 荒れが雑音の主原因であるとすれば，本挆傷機では 0.05 $\mathrm{mm}$ 深さの疵まで検出しうることを示している. しかし

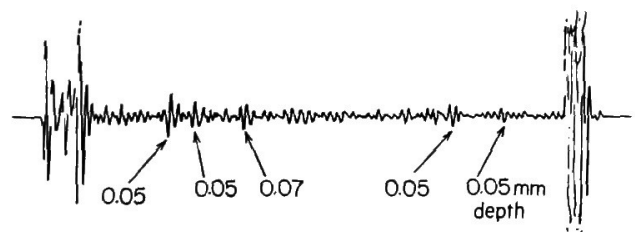

ENO 227 -7

Fig. 4. Record of flaw signals for austenitic stainless steel wire rod without vibration.

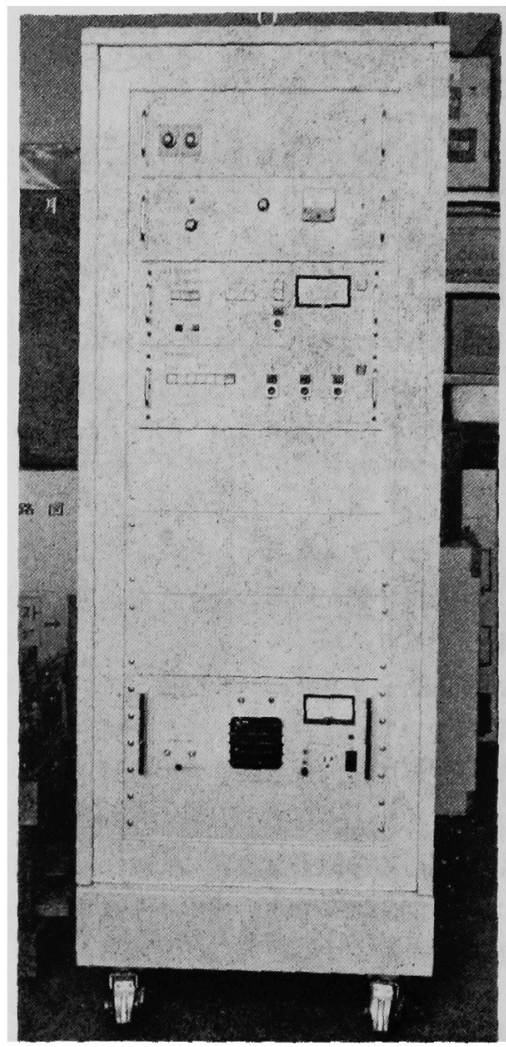

Photo. 2. Eddy current flaw detector.

一方, 圧延中の $5.5 \mathrm{~mm}$ 径の線材を搬送周波数 $40 \mathrm{kHz}$ で探傷した場合，雑音のため $0.15 \mathrm{~mm}$ 深さの㾟までこ そ検出しえなかつたことから，圧延中に発生する雑音源 は主として線材の振動にあると考えた。

次に, 周被数解析器により，雑音の周波数分布を求め

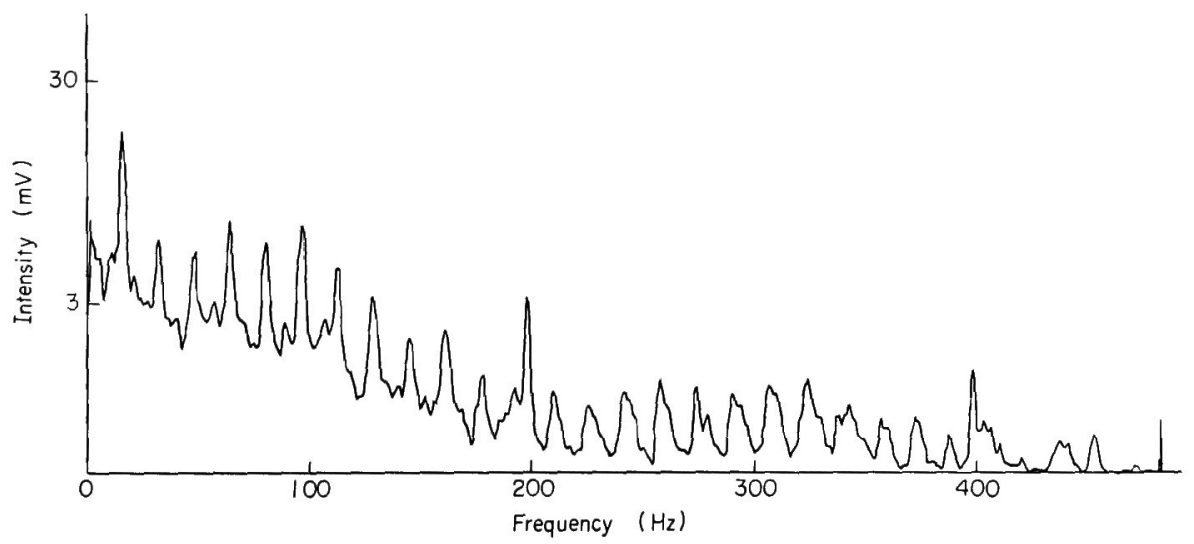

Fig. 5. Frequency spectrum of noise. Peaks appear at $16 \mathrm{~Hz}$ and its harmonics. 


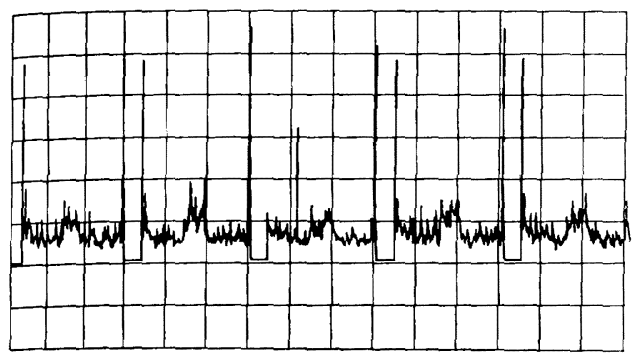

a)

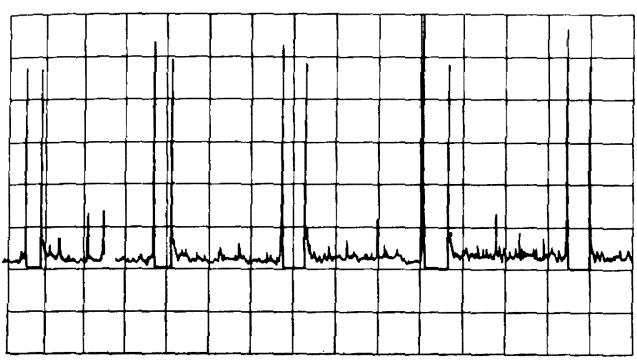

b)

Fig. 6. Change of noise level with mill roll balancing. a) common condition. b) finely ballanced condition.

た. Fig. 5 に周波数分布の1例を示した. Fig. 5 によ れば, $16 \mathrm{~Hz}$ の基本波と高次の高調波が明確に現われて おり,もとの波形に繰り返し周波数 $16 \mathrm{~Hz}$ のパルス波 を含んでいることがわかる、圧延機の仕上ロールの回転 数は毎秒 16 回転であり,上記の周波数と全く一致する. このことから，仕上ロールの1回転ごとに生じる衝整が 線材に伝わり，線材を振動させ，これが雑音となつて検 出されるものと推察される.

また，Fig. 6(a) に一般のロールを使用した場合， Fig. 6(b) に, 特に精密にバランスをとつたロールを 使用した場合の記録を比較して示した．明らかに精密に バランスをとつたロールの方が雑音が小さく，このこと からも，線材の振動が，雑音の主原因であることがわか る. 雑音の主原因が線材の振動に起因することについて は，他の線材圧延ラインでも経験しており，本探傷機を 適用した圧延機のみに，特有の問題ではないと考えられ る.

なお，線材の振動により雑音が発生する理由は，検出 コイル中の磁界分布が不均一であり，検出コイル中の線 材の位置によつてコイルインピーダンスが変化するため であると考えられる。

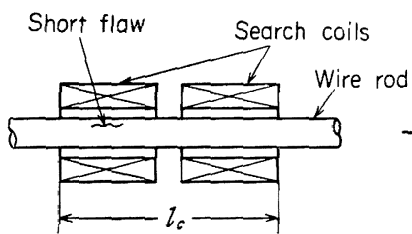

Wave form from short flaw

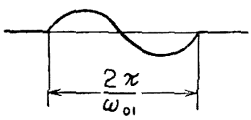

a)

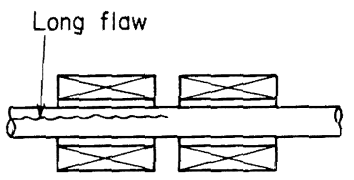

Wave form from long flaiv

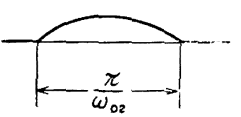

b)

Fig. 7. Wave forms of flaw signals, a) from short flaw and b) from long flaw.

\section{4. 疵信号と雑音との弁別}

\section{1 周波数弁別}

疵信号の周波数分布については，実際の疵信号から周 波数解析器により求めた結果がすでに報告されている6). 筆者らは，压延中の疵信号の周波数解析を試みたが，雑 音の影響で確実なものが得られなかつたので，数式によ。 り検討した.

コイル長さに比べて長さの短い淑がコイルを通過する ときの信号をFig. 7(a) に示すよう正弦波形の一周期 分上みれば，その周波数 $f_{01}$ は

$$
f_{01}=v / l_{c}
$$

である・ただし，v湶材走行速度， $l_{c}$ はコイル長さで ある、また，コイル長さに比べて長い一定深さの疵の先 端がコイルを通過する場合の㾟信号は Fig. 7(b) に示 すようであり，これを正弦波形の半周期分と夕れば，そ の周波数 $f_{02}$ は

$$
f_{02}=v / 2 l_{c}
$$

である.

Fig. 7(a) の信号波形を

$g_{1}(t)= \begin{cases}\sin \omega_{01} t, & 0 \leqq t \leqq 2 \pi / \omega_{01} \\ 0, & t<0, t>2 \pi / \omega_{01}\end{cases}$

とすると, 周波数分布 $G_{1}(\omega)$ は

$G_{1}(\omega)$

$=\left\{\begin{array}{c}\frac{1}{\omega_{01}} \cdot \frac{1}{1-\left(\omega / \omega_{01}\right)^{2}} \sqrt{\left(1-\cos 2 \pi \omega / \omega_{01}\right)^{2}+\left(\sin 2 \pi \omega / \omega_{01}\right)^{2}}, \\ \begin{array}{c}\omega \neq \omega_{01}, \\ \pi / \omega_{01}, \quad \omega=\omega_{01}\end{array} \ldots \ldots \ldots \ldots \ldots \ldots \ldots \ldots \ldots \ldots \ldots \ldots \ldots \ldots \ldots \ldots \ldots \ldots \ldots \ldots \ldots \ldots\end{array}\right.$ 
である*.ただし， $\omega_{01}$ は角周波数で， $\omega_{01}=2 \pi f_{01}$ であ る.

また，Fig. 7 b) の信号波形を

$$
g_{2}(t)= \begin{cases}\sin \omega_{02} t, & 0 \leqq t \leqq \pi / \omega_{02} \\ 0 & , \quad t<0, t>\pi / \omega_{02}\end{cases}
$$

とすると, 周波数分布 $G_{2}(\omega)$ は $G_{2}(\omega)$

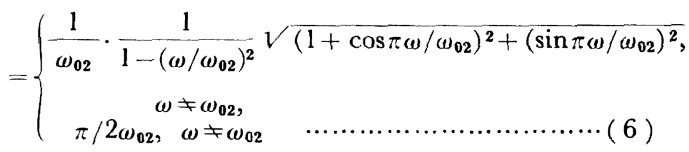

である*.ただし， $\omega_{02}=2 \pi f_{02}$ である.

(4) 式と（6）式を図示したのが，それぞれ Fig. 8 a), b) である. Fig. 8 a ), b) をみると, 周波数分 布は $\omega_{01}$ または $\omega_{02}$ を中心として広く分布しているこ とがわかる.

実際の使用例 $l_{c}=31 \mathrm{~mm}, v=16 \mathrm{~m} / \mathrm{sec}$ について(1), （2）式により算出した $f_{01} ， f_{02}$ はそれぞれ $520 \mathrm{~Hz}$, $260 \mathrm{~Hz}$ である. Fig. 5 によれば雑音の高調波は 400 $\mathrm{Hz}$ まで分布しており, 疵信号の周波数带と雑音の周波
数带が重なつている範囲がかなりあり，周波数フィルタ によつて疵信号を雑音より十分分膗することはできない と考えられる。実際使用時にて，バンドパスフィルタの 下限值を上げてゆくと，200 $\mathrm{Hz}$ 程度までは雑音が減衰 し，战信号検出感度が向上するが，200 Hz 以上にする と雑音はあまり減衰せず，むしろ疵信号の減衰が大きく なり，かえつて疵検出精度が落ちる．このことは，Fig. 7 b ) に示すような疵が多いと考えれば，フィルタの下 限值を $f_{02}=260 \mathrm{~Hz}$ 以上にすると，Fig. $8 \mathrm{~b}$ ) より廐 信号が $1 / 2$ に減衰することから推察される.

以上のように，疵信号と線材の振動に起因する雑音の 周波数弁別には限界があると考えた.

\section{2 位相角表示器}

本装置の位相表示器上にコイルインピーダンス変化が どのように表示されるかについて述べる.

ブリッジが平衡している場合，Fig. 2 に示すごとく， 2 個の検出コイルのインピーダンスを $Z_{1}, Z_{2}$, ブリッ ジの対辺の抵抗を $R_{1}, R_{2}$ とする. いま，一方のコイル インピーダンス $Z_{1}$ が $Z_{1}+\Delta Z_{1}$ に変化したとき, ブリ ッジの出力電压 $\Delta E_{\mathrm{o}}$ は
* 本文の Fig. 7 a) の信号波形を, Fig. Al a),

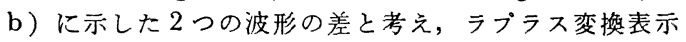
にて表わせば,

$$
\begin{aligned}
G_{1}(s) & =\frac{\omega_{01}}{s^{2}+\omega_{01}{ }^{2}}-\frac{\omega_{01}}{s^{2}+\omega_{01}{ }^{2}} e^{-s 2 \pi / \omega_{01}} \\
& =\frac{\omega_{01}}{s^{2}+\omega_{01}{ }^{2}}\left(1-e^{-s 2 \pi / \omega_{01}}\right) \cdots \cdots \cdots . . . .
\end{aligned}
$$

となる.（A1）式の $s$ を $j \omega$ におきかえ絶対值をとれば 周波数分布が求まる. 寸なわち, $\left|G_{1}(j \omega)\right|=G_{1}(\omega)$ と表 わせば, $e^{j \theta}=\cos \theta+j \sin \theta$ の関係から

$G_{1}(\omega)$

$$
=\frac{1}{\omega_{01}} \cdot \frac{1}{1-\left(\omega / \omega_{01}\right)^{2}} \sqrt{\left(1-\cos 2 \pi \omega / \omega_{01}\right)^{2}+\left(\sin 2 \pi \omega / \omega_{01}\right)^{2}}
$$

となる.（A2）式は $\omega=\omega_{01}$ で不定となるので, 三角関 数を $2 \pi$ の付近でテーラ展開し, かつ, $\sin 2 \pi \omega / \omega_{01}=$ $\sin 2 \pi\left(1-\omega / \omega_{01}\right)$ から,

$$
\lim _{\omega \rightarrow \omega_{01}} G_{1}(\omega)=\lim _{\omega \rightarrow \omega_{01}} \frac{1}{\omega_{01}} \cdot \frac{2 \pi}{\left(1+\omega / \omega_{01}\right)}=\frac{\pi}{\omega_{01}}
$$

と求められる。

本文の Fig. 7 b) の波形も同様に, Fig. A 2 に示し た 2 つ波形の和と考え，ラプラス変換表示にて表わせ ば,

$$
G_{2}(s)=\frac{\omega_{02}}{s^{2}+\omega_{02}^{2}}\left(1+e^{-s \pi / \omega_{02}}\right)
$$

となる. 以下，Fig. 7 a) の波形と同様な方法で（6) 式が導かれる.

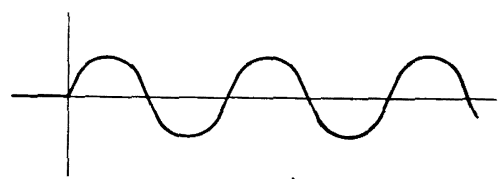

a)

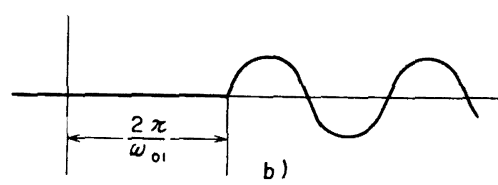

Fig. Al a) Sine wave function starting at ${ }^{\top} t=0$ and $b$ ) sine wave function starting at $t=2 \pi / \omega_{01}$. Wave form in Fig. $7 \mathrm{a}$ ) is the difference of $a$ ) and $b$ ).

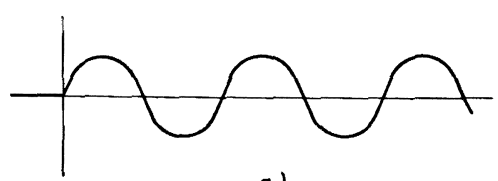

a)

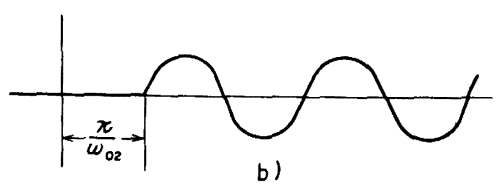

Fig. A 2 a) Sine wave function starting at $t=0$ and b) sine wave function starting at $t=\pi / \omega_{02}$. Wave form in Fig. $7 \mathrm{~b}$ ) is the sum of $a$ ) and $b$ ). 


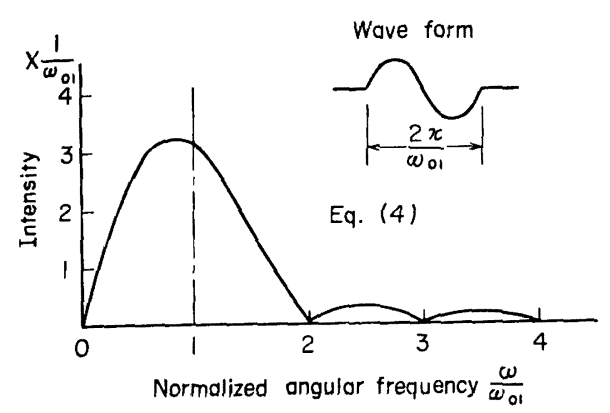

a)

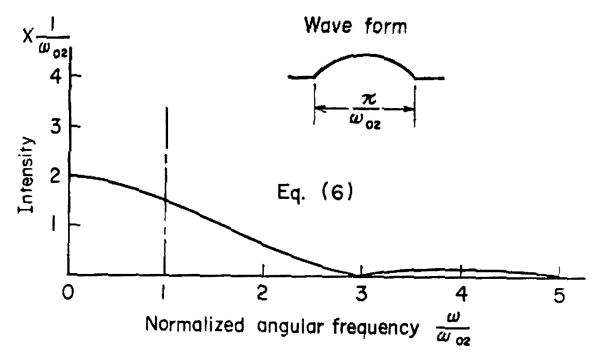

b)

Fig. 8. Calculated frequency spectra of flaw signals a ) from short flaw and b) from long flaw.

$$
J E_{0}=E_{\mathrm{s}}\left(\frac{Z_{1}+\Delta Z_{1}}{Z_{1}+\Delta Z_{1}+Z_{2}}-\frac{Z_{1}}{Z_{1}+Z_{2}}\right)
$$

である.ここで， $E_{\mathrm{s}}$ はブリッジ電源電死である. 一般 に，検出しうる最小の疵によるインピーダンスの変化割 合 $\Delta Z_{1} / Z_{1}$ は 10-4 10-5 であるので（7）式の括弧内 の第 1 項を展開し， $\Delta Z_{1} /\left(Z_{1}+Z_{2}\right)$ の1次の項まで採る と（7）式沖

$$
\Delta E_{\mathrm{o}}=E_{\mathrm{s}} \frac{Z_{2}}{Z_{1}+Z_{2}} \cdot \frac{\Delta Z_{1}}{Z_{1}+Z_{2}} .
$$

となる. 2 個のコイルは同形のものを使用しているから

(8) 式において $Z_{1}=Z_{2}$ とすると，（8）式は

$$
\frac{\Delta E_{\mathrm{o}}}{E_{\mathrm{s}}} \fallingdotseq \frac{1}{4}-\frac{J Z_{1}}{Z_{1}}
$$

となる・

ブラウン管の $\mathrm{X}$ 軸， $\mathrm{Y}$ 軸への入力は，ブリッジ電源電 压位相角を基準としているから，ブラウン管上に現われ るベクトルは $\Delta E_{\mathrm{o}} / E_{\mathrm{s}}$ であり，これは（9）式により， $\Delta Z_{1} / Z_{2}$ である.すなわち，ブラウン管上に現われるべ クトルのX軸となす角は, インピーダンス $Z_{1}$ の位相角 とインピーダンス変化分 $\Delta Z_{1}$ の位相角の差である. た，ベクトルの絶対值は，インピーダンスの变化割合 $\Delta Z_{1} / Z_{1}$ に比例した値である.この関係を Fig. 9 a )，

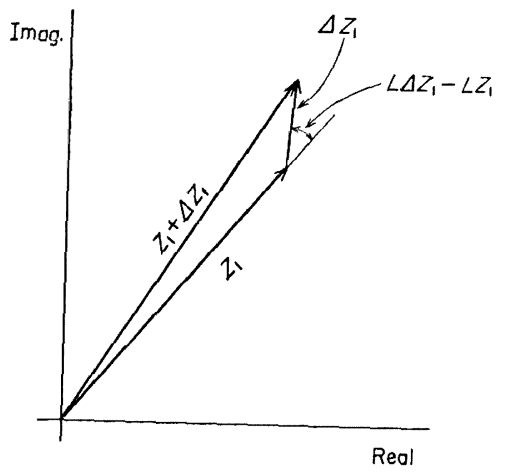

a)

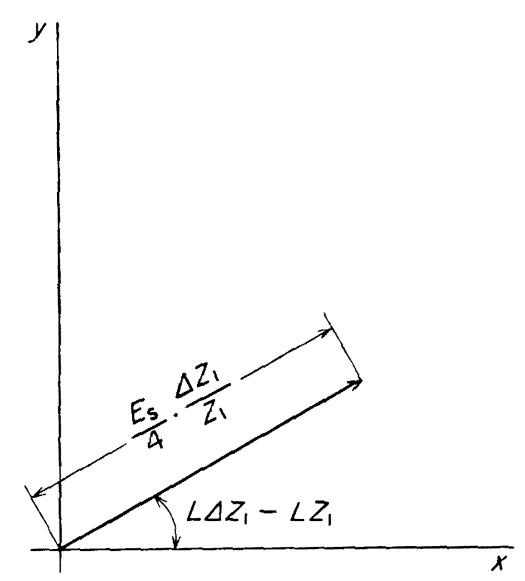

b)

Fig. 9. a ) Vector diadram of search coil impedance and its deviation, and b) impedance deviation appeared on signal phase display.

b）に図示した。

\section{3 位相弁別}

位相弁別の対象となるものとして，疵信号之材料径の 変化によつて, 信号の位相角が異なること, 㾟の開口度に より位相角が異なることがすでに $F$ ，FÖRSTERによつて 論じられている7゙.また,材料径の変化によるコイルイン ピーダンスの変化, および電気伝導度の変化によるコイ ルインピーダンスの変化についての解析解が $F$. FÖRSTER によつて求められている8). 同様のことが $R$. HOCHSCHILD によつてもまとめられており， $R$. HochsCHILD は両者 の信号を位相弁別するために位相角の差を大にするには

$$
g \cdot a=\sqrt{\omega_{c} \sigma \mu} \cdot a \geqq 3
$$

のように搬送周波数を選ぶことが必要であると述べてい 
る9). $\omega_{\varepsilon}$ は搬送波の角周波数, $\sigma$ 惯気伝導度である. $\mu$ は透磁率であり, キューリ一点以上の温度で注，真空 の透磁率 $4 \pi \times 10^{-7}$ にほとえど等しい，また，a沂 料半径である.

しかしここで問題となつているのは疵信号と線材の 振動に起因寸る雑音との位相弁別であるが，これを解析 的に求めることは困難である.このため，(10) 式の条 件が，疵信号と線材の振動に起因する雑音の位相弁別に も括よそあてはをると想定し，搬送周波数を决定した。

本探偟機を適用した压延機では， $5.5 \mathrm{~mm}$ 径の線材の 压延が多く行なわれるため，5.5 mm 径に対する搬送周 波数学求める. $5.5 \mathrm{~mm}$ 径とは直径 $5.5 \mathrm{~mm}$ から 5.9 $\mathrm{mm}$ までを指しており， $a=2.75 \times 10^{-3} \mathrm{~m} \sim 2.95 \times 10^{-3}$ $\mathrm{m}$ であり， $\sigma_{900}{ }^{\circ} \mathrm{C}=0.854 \times 10^{6} \ddot{E} / \mathrm{m}$ であるから, 最初製 作した探傷機で採用した搬送㓮波数 $40 \mathrm{kHz}$ の場合は, $g \cdot a=1.43 \sim 1.53$ となる. $160 \mathrm{kHz}$ 在使用する場合は, $g \cdot a=2.85 \sim 3.06$ となり, (10) 式の条件を満足してい る.よつて新しく製作する探傷機では最高搬送周波数を $160 \mathrm{kHz}$ とした. R. HocHSCHILD によれば， $g \cdot a$ を3

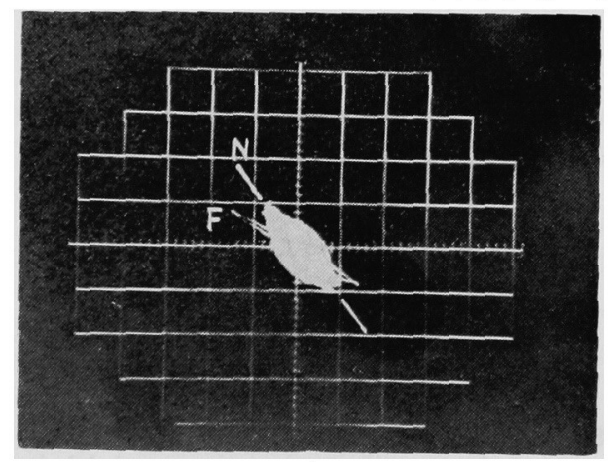

a )

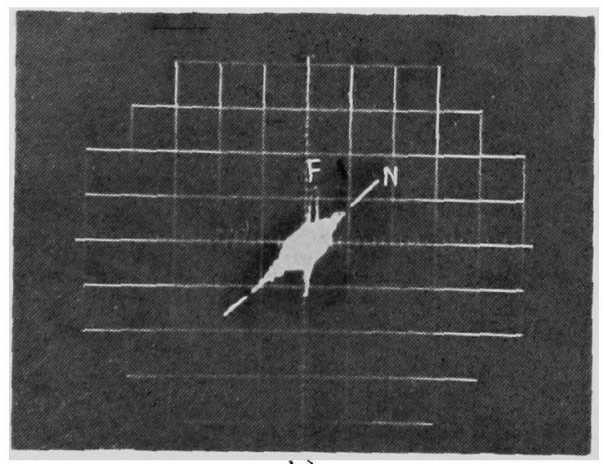

b )

Fig. 10. Change of phase difference between flaw vector $\mathrm{F}$ and noise vector $\mathrm{N}$ with carrier frequency. a) Phase difference is $25^{\circ}$ in the case of $40 \mathrm{kHz}$ carrier frequency and b) $45^{\circ}$ in the case of $160 \mathrm{kHz}$.
より大きい值にとつても位相差はあまり増加せず,す巳て ろ高い周波数を採用することによる装置製作上の問題が 起きるので，あ元て $160 \mathrm{kHz}$ 以上の周波数を採用する 必要はない。

搬送周波数に $40 \mathrm{kHz}$ を使用した探偒機と $160 \mathrm{kHz}$ を使用した探傷機について，王延中における疵信号と雑 音との位相角の差を比較した。 Fig. 10 a), b) は, $5.5 \mathrm{~mm}$ 径の線材に対して, それぞれ 搬送周波数が 40 $\mathrm{kHz}$ および $160 \mathrm{kHz}$ の場合についての位相角表示器に 表われた疵ならびに雑音のベクトル軌跡である.これは オンラインデータをいつたんデータレコーダに収録し, 疵信号のある付近を選えで再現したものである. Fig. 10 a)，b）にみられるように，線材の振動による雑音の ベクトルの方向はあらゆる方向䘮持つているが，ある方 向 (Fig. 10 の) でベクトルの大きさは最大值を示し ている.この最大值の位相角と疵信号の位相角の差は, 搬送周波数が $40 \mathrm{kHz}$ の場合が $25^{\circ} ， 160 \mathrm{kHz}$ の場合 が $45^{\circ}$ であり， $160 \mathrm{kHz}$ の場合の方が位相弁別にとつ て有利であることがわかる。

Fig. 10 a )， b ）の場合は，2で述べた検出コイルを 使用しているが，阔波数弁別の効果をあげる目的で疵周 波数すなわち（1），(2) 式に括汁る $f_{01} ， f_{02}$ を小さく するように $l_{c}=10 \mathrm{~mm}$ の検出コイルを用いて実験を行 なつた。しかし，特に周波数弁別の効果は游がらず，ま た， $160 \mathrm{kHz}$ の搬送周波数を用いても，疵信号之雑音の 位相差什大点くならず，位相弁别の効少はなかつた。

また，常温にてオーステナイト系ステンレス鋼の材料 を検出コイル中にて位置を变え, 位相の変化を調查し た. 材料の中心軸が検出コイルの中心軸と平行を保つよ うにして材料を移動したところ，位相はある一定值を示 し，材料をコイルの中心䡅に対し傾斜させた場合，傾斜 㑇度に対して位相は異なつた值を示した。.Fig. 10 a), b）に示したように雑音が㮔々の位相を有し，かつ，一 定位相角にて最大值を示していることは, 線材が検出コ イル軸に刘して，平行な振動と傾斜する振動を含んでお り，平行な振動が雑音として大きく現われているものと 推察される.

\section{5. 圧延時における位相弁別の効果}

$160 \mathrm{kHz}$ の搬送周波数を优用したことによる位相弁別 の効果を確認するため, 搬送周波数 $40 \mathrm{kHz}$ の挆傷機と $160 \mathrm{kHz}$ の探傷機を使用して，同一線材について同時探 傷を行なつた。探倠記録を Fig. 11 a)，b）に示す. 線材径は $5.5 \mathrm{~mm}$ である. また，Fig. $11 \mathrm{c}$ ）に目視検 查の結果を示す、疵深さの測定は酸洗後, 疵が消失する 


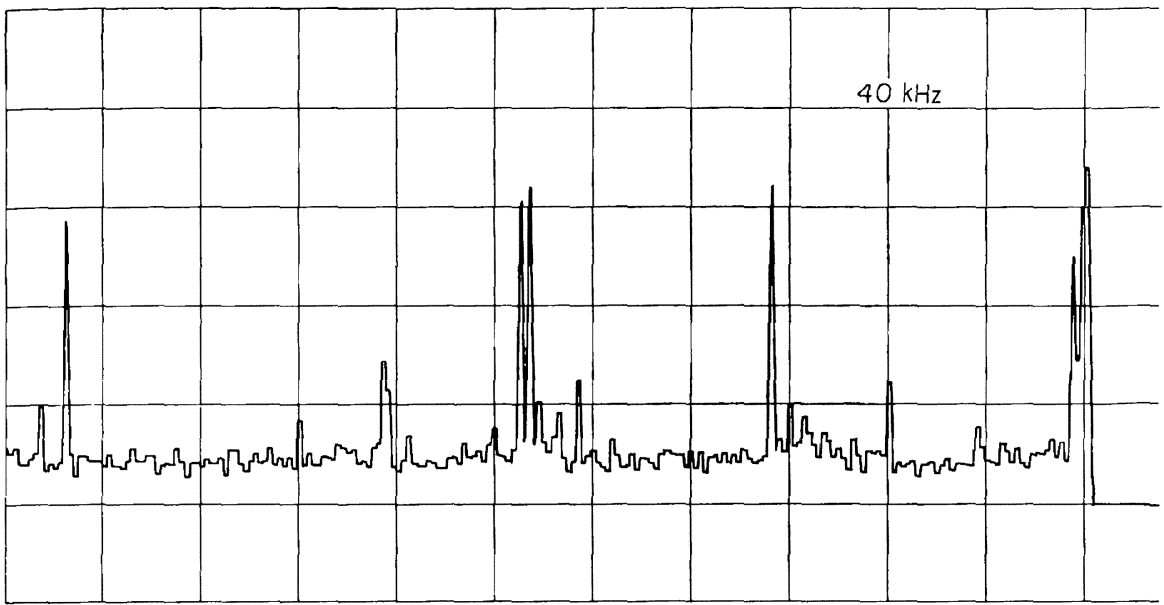

a)

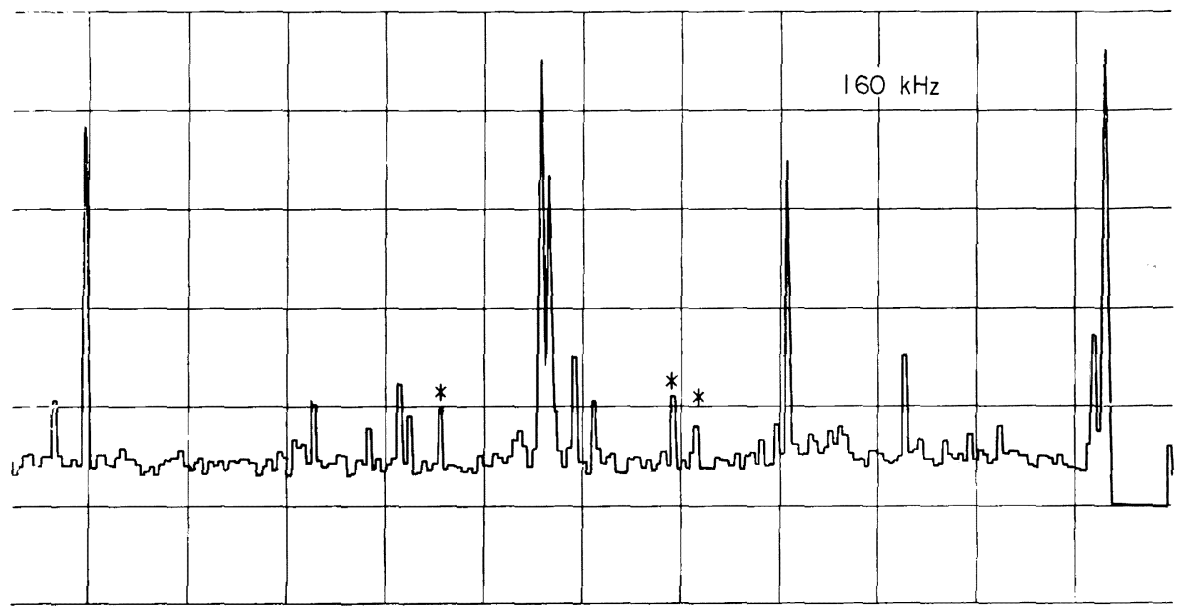

b)

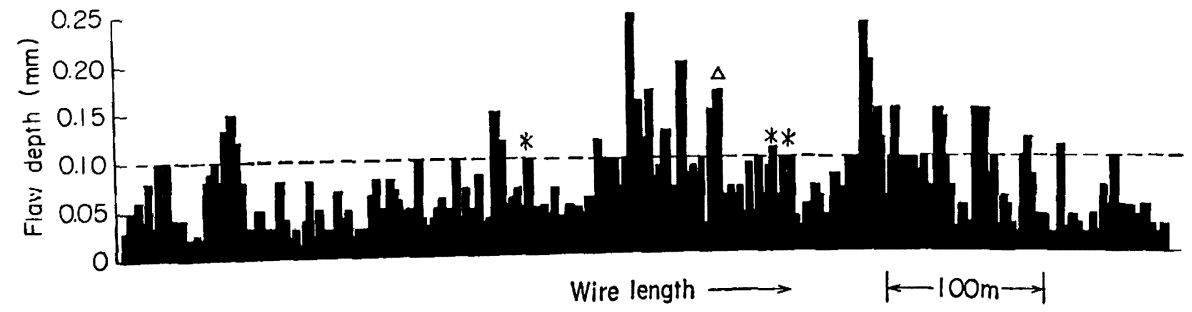

c)

Fig. 11. Detecting records for $5.5 \mathrm{~mm}$ dia. wire rod by two kinds of flaw detectors : a ) Carrier frequency is $40 \mathrm{kHz}$ and b) $160 \mathrm{kHz}$. c) Result of human inspection. Flaws with * mark are detected only by flaw detector with $160 \mathrm{kHz}$ carrier frequency. Flaw with $\triangle$ mark is long seam and cannot be detected by both flaw detectors. 
までやすりがけし，削り代を測定する方法である，線材 を $3 \mathrm{~m}$ ごこに区分し，各区分の中で最も深い訿の值を代 表値として示した. 探倠機で検出した疵は目視検査の結 果とほとえど一致している。罒中*印で示した $0.1 \mathrm{~mm}$ 深さの疵は $160 \mathrm{kHz}$ では明らかに検出されているが, $40 \mathrm{kHz}$ では雑音レベル以下となり，まつたく検出され ていない.また，160 kHzの方が全般的に疵信号レベル が高く，S/N がよいことがわかる。なお，Fig. 11 a) とｂ）は，両者の雑音レベルが同一になるようにゲイ ン調整して記録した. $\triangle$ 印で示した㾟は両探傷機とも検 出していないが，この㾟は $2 \mathrm{~m}$ にたつて深さがゆるや かに変化している線状疵であり，自己比較型のコイルを 使用しているため原理的に，このような㾟は検出しにく い. その他の疵はへゲ疵またはオレコ々である.

以上のごとく，5.5 mm 径の線材に対しては $160 \mathrm{kHz}$ の搬送周波数を使用して位相弁別を行なうことが疪検出 精度向上に有効であることがわかつた.

\section{6. 疵の検出例}

$160 \mathrm{kHz}$ の探傷機により検出した疵の例を述べる. Photo. $3 \mathrm{a}$ ), b) はへゲ疵の例である. 深さは $0.1 \mathrm{~mm}$ である. Photo. 4 はオレ疵の例で深さ $0.6 \mathrm{~mm}$ である. この疵のある線材コイルの全長の探傷記録打よび目視检 査結果は, Fig. 12a), b) に示すごとくであり，0.1 $\mathrm{mm}$ 深さの疵まで検出している. Photo. 4 の疵は Fig. 12 b) に*印で示したものである。また, Photo. 5 㳉
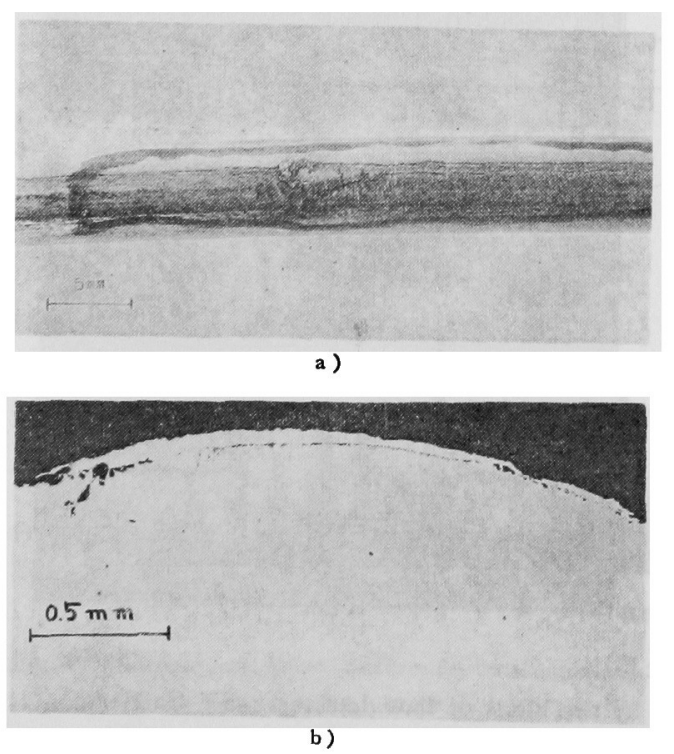

Photo. 3. Microscopic photograph of scab. a) appearance and (b) cross section.
直径 $1 \mathrm{~mm}$ 程度の酸化物をかみ込えだものである.こ のようなコイル長に比して短い欠陷でもよく検出してい る. Photo. 6 は線材中心部に発生したワレ状の欠楩であ る.この樎は従来の目視検査では発見できないもので ある．Fig. 13 に探傷記録を示したごとく確实に検出し

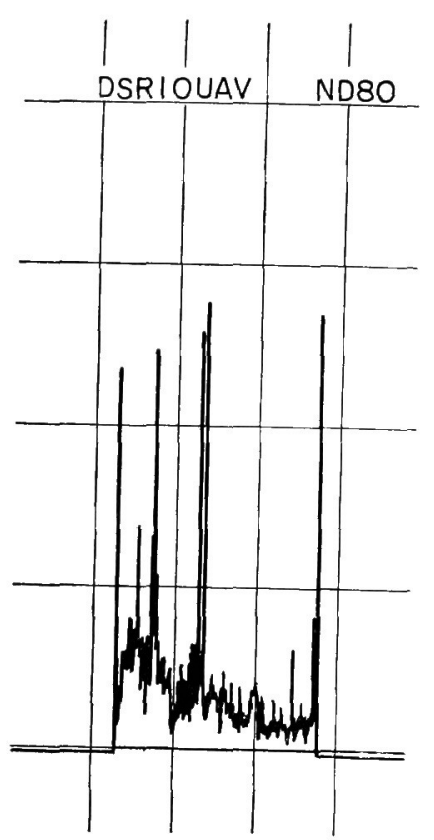

a)

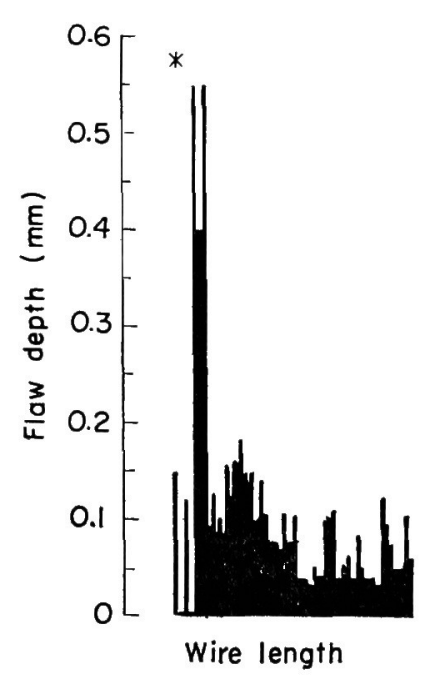

b)

Fig. 12. One example of a ) detecting record and b) human inspection. 


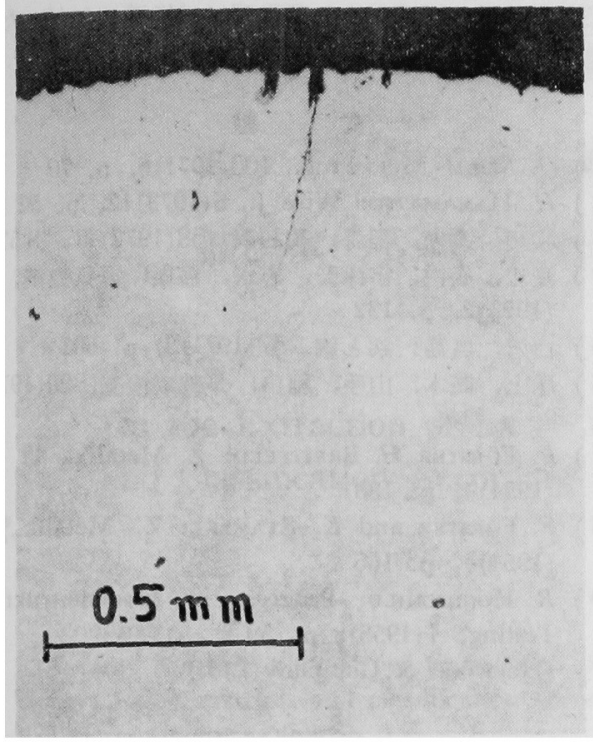

Photo. 4. Microscopic photograph of crack shown in Fig. 12 by *.

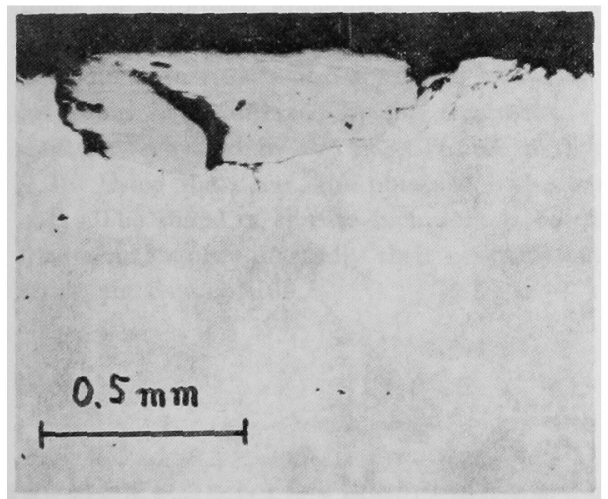

Photo. 5. Microscopic photograph of inclusion.

ている.

\section{7. 結言}

熱間渦流探㑑機の雑音の解析を行ない，以下に述心゙る よう，疪検出精度を向上させた装置起閶発した。

1) 雑音は主として線材の振動に起因寸るものであり この振動は压延ロールの振動が伝わつたものであるとと を確認した。

2) また雑音はパルス状波を念九でおり, 周波数分在 はかなり高い周波数までに拈よんでいる. 一方, 㾟信号 の周波数分布は低域までにおよぶ広い範囲に分有してい るので周波数升別のみで疵検出精度を向上させることに は限界があることがわかつた。

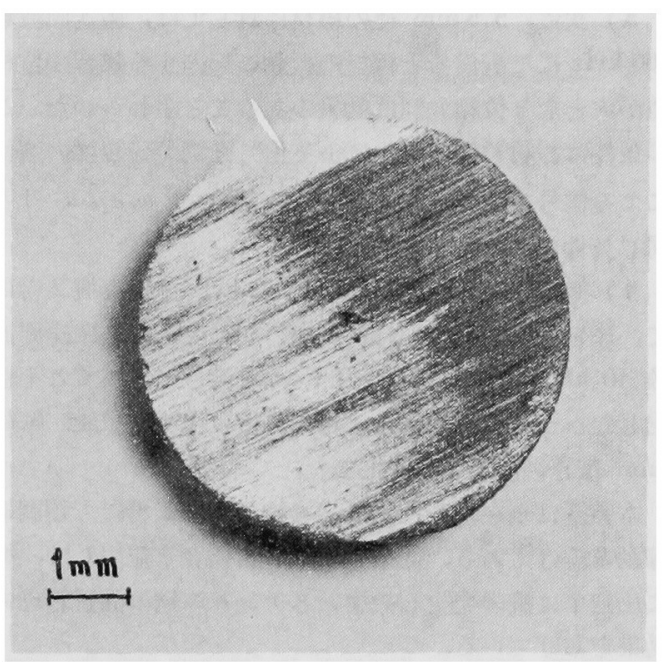

Photo. 6. Ciross section of pipe.

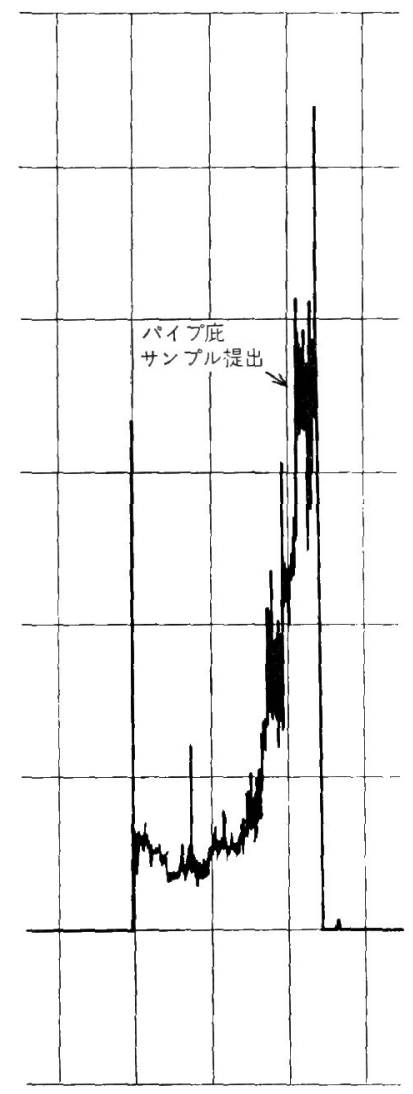

Fig. 13. Detecting record of pipe shown in Photo. 6. 
3 ) 次に, $5.5 \mathrm{~mm}$ 径の線材に対しては, 搬送周波数 $160 \mathrm{kHz}$ にて疵信号と線材の振動に起因する雑音の位相 差が大となり位相弁別に効果のあることがわかつた.こ の条件は，材料径の变化による信号と電気伝導度の変化 による信号を十分位相弁別できる条件, $\sqrt{\omega_{c} \sigma \mu} \cdot a=3$ と 同じ条件である.

4 ) 搬送周波数 $160 \mathrm{kHz}$ と $40 \mathrm{kHz}$ の探傷機 2 台に て, 压延中の線材の同時探伤を行なつた結果, 搬送周波 数 $40 \mathrm{kHz}$ の探傷機では $0.15 \mathrm{~mm}$ 深さの疪までこそ検 出しなかつたのに対して, $160 \mathrm{kHz}$ の探傷機では 0.10 $\mathrm{mm}$ 深さの疵まで検出しえた。

本装置は現在, 当社星崎工場線材圧延工場にて順調に 稼動を続けており, 彷来の端末試料検査と並用して, 特 に圧延中に疵の発生しやすいステンレス鋼の品質管理に 効果をあげている.

筆を置くにあたり，本研究の推進にご尽力いただいた 大同製鋼 (株) 取締役研究開発本部長藤原達雄氏および星
崎工場任延課の諸氏，また理論面でご指導いただいた名 古屋大学教授丸勢進氏に厚くお礼申し上げます.

\section{文献}

1) O. Miki: Met. Prog., 100(1971)6, p. 70

2) H. Hamamatsu: Wire J., 6(1973) 12, p. 52

3 ）渡辺，武内，稲森：鉄と鋼，58(1972)11，S 570

4 ) 渡辺, 武内, 宇津野, 志水, 稲森: 電気製鋼, 44 (1973) 2, p. 132

5 ) 白岩, 広島: 鉄と鋼, $57(1971) 3$, p. 601

6 ) 尾上, 高木, 山手, 稲田: 非破壊検査, 20(1971) 8, p. 344

7) F. Förster $H$. Breitfeld: Z. Metallk., 45 (1954) 4, p. 188

8 ) F. Förster and $K$. Stambke: Z. Metallk., 45 (1954) 4, p. 166

$9)$ ) Hochschild: Progress in Non-destruktive Testing, 1 (1958), p. 59

[Heywood \& Company Ltd.] 